Фармакологічні дослідження біологічно активних речовин

Pharmacological researches of biologically active substances

УДК 615.014.07:615.28:582.795.14

DOI https://doi.org/10.11603/2312-0967.2019.1.9950

\title{
ВИЗНАЧЕННЯ АНТИМІКРОБНОЇ АКТИВНОСТІ БЕДРИНЦЮ ЛОМИКАМЕНЕВОГО ЕКСТРАКТУ ГУСТОГО
}

\author{
Е. А. Паращук, Н. І. Ткачук, С. М. Марчишин, Г. Р. Козир
}

ДВНЗ «Тернопільський державний медичний університет імені І. Я. Горбачевського МОЗ України»

svitlanafarm@ukr.net

\begin{abstract}
Мета роботи. Визначення антимікробної активності бедринцю ломикаменевого підземних органів екстракту густого.

Матеріали і методи. Об'єктом для дослідження обрано бедринцю ломикаменевого підземних органів екстракт густий (БЕГ-1, одержаний екстрагуванням 75 \% етанолом і БЕГ-2, екстрагент 85 \% етанол). В якості тест-культур використовували 5 музейних штамів: грампозитивні мікроорганізми Staphylococcus aureus ATCC 6538, спорову культуру Bacillus subtilis ATCC 6633, грамнегативну культуру Escherichia coli ATCC 25922 та Pseudomonas aeruginosa ATCC 9027. Антифунгальну дію з'ясовували відносно Candida albicans ATCC 885-653.

Бактеріостатичні властивості досліджуваних об'єктів встановлювали за результатами росту еталонних штамів мікроорганізмів у нативному водному розчині бедринцю та в розведені 1:2 та 1:4 в м'ясо-пептонному бульйоні; бактерицидні - за відсутністю росту вмісту пробірок із розведенням екстракту на щільних поживних середовищах (м'ясо-пептонний агар - МПА) для грампозитивних мікроорганізмів S. aureus, B. subtilis, для грамнегативної культури E. coli, P. aeruginosa. Агар Сабуро використовували для дріжджеподібних грибів роду Candida (C. albicans). Результати й обговорення. Бедринцю ломикаменевого підземних органів екстракт густий має широкий спектр антибактеріальної активності. Нативний екстракт БЕГ-1 по відношенню до тест-штамів S. aureus, B. subtilis, C. albicans проявляв бактерицидну дію. Бактеріостатичну дію він проявляв до $P$. aeruginosa, а по відношенню до E. coli антимікробного ефректу не виявлено. Екстракти в розведені 1:2 та 1:4 проявили бактерицидну дію відносно B. subtilis, бактеріостатичну - до S. aureus, C. albicans і не виявлено протимікробної дії до E. coli та P. aeruginosa. Нативний зразок БЕГ-2 по відношенню до усіх досліджуваних 5 тест-штамів проявив бактерицидну активність; у розведені 1:2 та 1:4 проявляв бактерицидну та бактеріостатичну дію відносно S. aureus, B. subtilis, C. albicans. Антимікробна дія по відношенню до $E$. coli та $P$. aeruginosa не виявлена.

Антимікробну активність нативного бедринцю ломикаменевого екстракту густого також вивчали у дослідах in vitro методом дифузії в агар - метод "колодязів". Штами S. aureus, C. albicans, B. subtilis, P. aeruginosa, E. coli проявили чутливість до нативного бедринцю ломикаменевого підземних органів екстракту густого. Грампозитивні бактеріальні штами S. aureus, a також гриби C. albicans, B. subtilis $€$ найбільш чутливими до БЕГ-2, а БЕГ-1 проявляв порівняно меншу чутливість. Грамнегативні культури $P$. aeruginosa тa $E$. coli також проявили помірну чутливість до БЕГ-1, але значно більшу чутливість до БЕГ-2.

Висновки. Експериментально встановлено, що обидва досліджувані зразки бедринцю ломикаменевого підземних органів екстракту густого проявляють антибактеріальну активність.

Бедринцю ломикаменевого підземних органів екстракт густий проявляв більш виражену антимікробну активність по відношенню до грампозитивної мікрофлори, тому є перспективним для створення лікарського засобу 3 антимікробними властивостями.
\end{abstract}

Ключові слова: бедринець ломикаменевий; екстракт густий; антимікробна дія.

Вступ. Кінець XX і перші десятиліття XXI століття характеризуються появою на фрармацевтичному ринку великої кількості синтетичних антибактеріальних лікарських препаратів. На цьому фоні і засоби з лікарських рослин (ЛР) як допоміжні препарати для терапії і профрілактики інфрекційних захворювань займають значне місце в медичній практиці.

Широке і часто безконтрольне або недостатньо аргументоване застосування сучасних антибактеріальних препаратів (насамперед антибіотиків) для профрілактики і лікування різноманітних інфекційних процесів призводить до швидкого зростання антибіотикорезистентності умовно патогенної мікрофрлори і власне збудників інфекційних захворювань. Тому завжди буде актуальним пошук нових протимікробних засобів, джерелом яких можуть бути і ЛР. ЛР містять біологічно активні речовини (БАР), які подібні за хімічною будовою до ряду речовин людського організму (до ферментів, гормонів, вітамінів тощо), тому при введені в макроорганізм вони активно включаючись в біохімічні процеси, позитивно впливають на організм людини в цілому, а деякі з них здатні проявляти

ISSN 2312-0967. Фармацевтичний часопис. 2019. № 1 
Фармакологічні дослідження біологічно активних речовин Pharmacological researches of biologically active substances

антибактеріальну дію. Це такі БАР, як ефірні олії, дубильні речовини, органічні кислоти, смоли, алкалоїди [1].

Відомо, що антимікробну дію проявляють багато ЛР $[1,2,3]$, проте у доступних нам джерелах літератури ми не знайшли інформації про вивчення антимікробних властивостей представника роду Бедринець (Pimpinella L.) з родини Селерові (Apiaceae) бедринцю ломикаменевого (Pimpinella saxifraga $L$ ), що застосовується в медичній практиці як засіб для комплексної терапії респіраторних захворювань як відхаркувальний засіб (при гострому катарі верхніх дихальних шляхів, фрарингіті, ларингіті, трахеїті, хронічному бронхіті). Відвар підземних органів бедринцю $є$ хорошим засобом при коклюші, ангіні і бронхіальній астмі, метеоризмі, захворюваннях печінки. Свіжий сік рослини використовується для виведення пігментних плям на шкірі $[4,5,6]$.

Вивчення хімічного складу надземних і підземних органів бедринцю ломикаменевого показало, що рослина містить сполуки фенольного характеру (фрлавоноїди, дубильні речовини, гідроксикоричні кислоти, кумарини), ефрірні олії, жирні та органічні кислоти (щавлеву, малонову, бурштинову і лимонну) $[7,8,9]$.

Мета роботи - визначення антимікробної активності густого екстракту підземних органів бедринцю ломикаменевого, одержаного на кафредрі управління та економіки фрармації з технологією ліків під керівництвом доц. Г. Р. Козир ДВНЗ «Тернопільський державний медичний університет імені І. Я. Горбачевського МОЗ України».

Матеріали і методи. Дослідження антимікробної дії проводили на базі лабораторії мікробіологічних досліджень дВНЗ «Тернопільський державний медичний університет імені І. Я. Горбачевського МОЗ України». Об'єкт дослідження - бедринцю ломикаменевого підземних органів екстракт густий (БЕГ-1, одержаний екстрагуванням 75 \% етанолом і БЕГ-2,

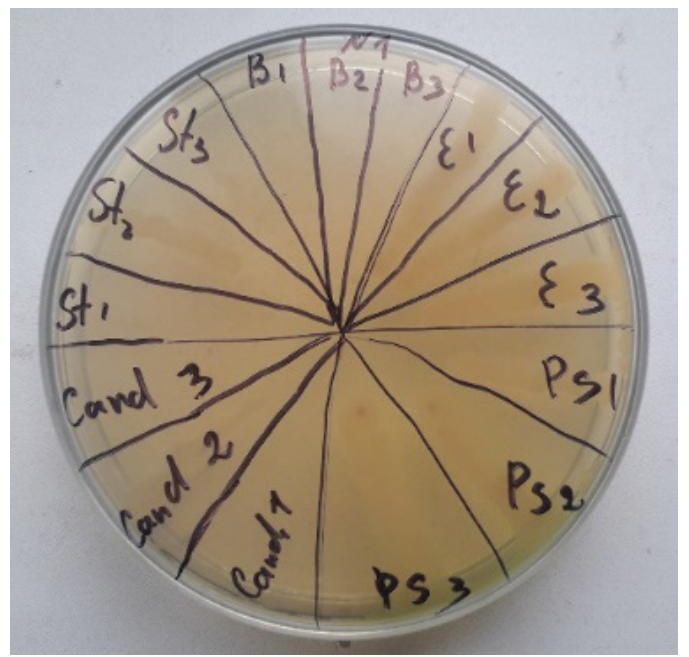

екстрагент 85 \% етанол). В якості тест-культур використовували 5 музейних штамів: грампозитивні мікроорганізми Staphylococcus aureus ATCC 6538, спорову культуру Bacillus subtilis ATCC 6633, грамнегативну культуру Escherichia coli ATCC 25922 та Pseudomonas aeruginosa ATCC 9027. Антисрунгальну дію з'ясовували відносно Candida albicans ATCC 885653.

Бактеріостатичні властивості досліджуваних об'єктів встановили за результатами росту еталонних штамів мікроорганізмів у нативному водному розчині бедринцю та в розведені 1:2 та 1:4 на м'ясопептонному бульйоні; бактерицидні - за відсутністю росту вмісту пробірок з розведенням екстракту на щільних поживних середовищах (м'ясо-пептонний агар - МПА) для грампозитивних мікроорганізмів S. aureus, B. subtilis, для грамнегативної культури E. coli, P. Aeruginosa. Аzар Сабуро використовували для дріжджеподібних грибів роду Candida (C. albicans) [10].

Результати й обговорення. Результати досліджень наведено на рисунках 1 і 2 та в таблиці 1.

За результатами проведених досліджень виявлено, що бедринцю ломикаменевого підземних органів екстракт густий має широкий спектр антибактеріальної активності. Проведені дослідження з БЕГ-1 показали, що нативний екстракт по відношенню до тестштамів S. aureus, B. subtilis, C. albicans проявляв бактерицидну дію. Бактеріостатичну дію він проявляв до $P$. aeruginosa, а по відношенню до E. coli антимікробного ефректу не виявлено.

Екстракти в розведені 1:2 та 1:4 проявили бактерицидну дію відносно B.subtilis, бактеріостатичну до S. aureus, C. albicans і не виявлено протимікробної дії до E. coli та $P$. aeruginosa.

При роботі із БЕГ-2 отримані результати свідчать про те, що нативний зразок по відношенню до усіх досліджуваних 5 тест-штамів проявив бактерицидну активність. Екстракт бедринцю ломикаменевого у

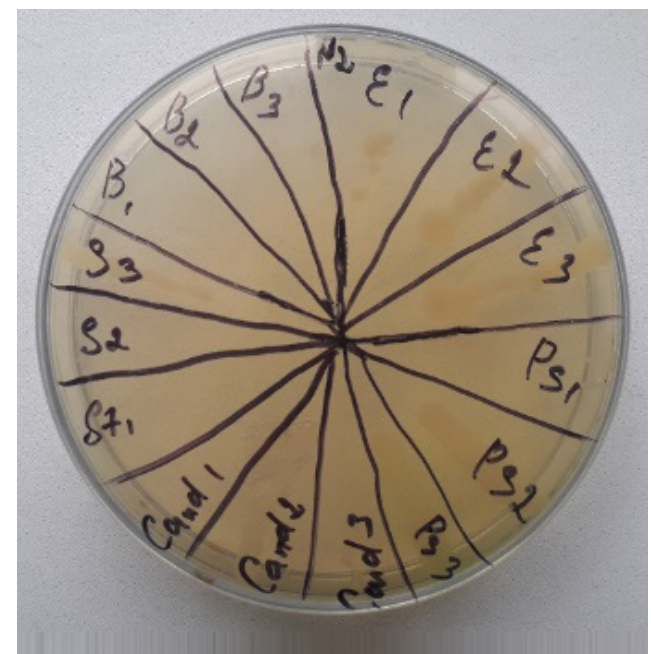

Рис. 1. Результати визначення чутливості тест-штамів до БАР бедринцю ломикаменевого екстракту густого (БЕГ-1).

ISSN 2312-0967. Pharmaceutical review. 2019. № 1 
Фармакологічні дослідження біологічно активних речовин Pharmacological researches of biologically active substances
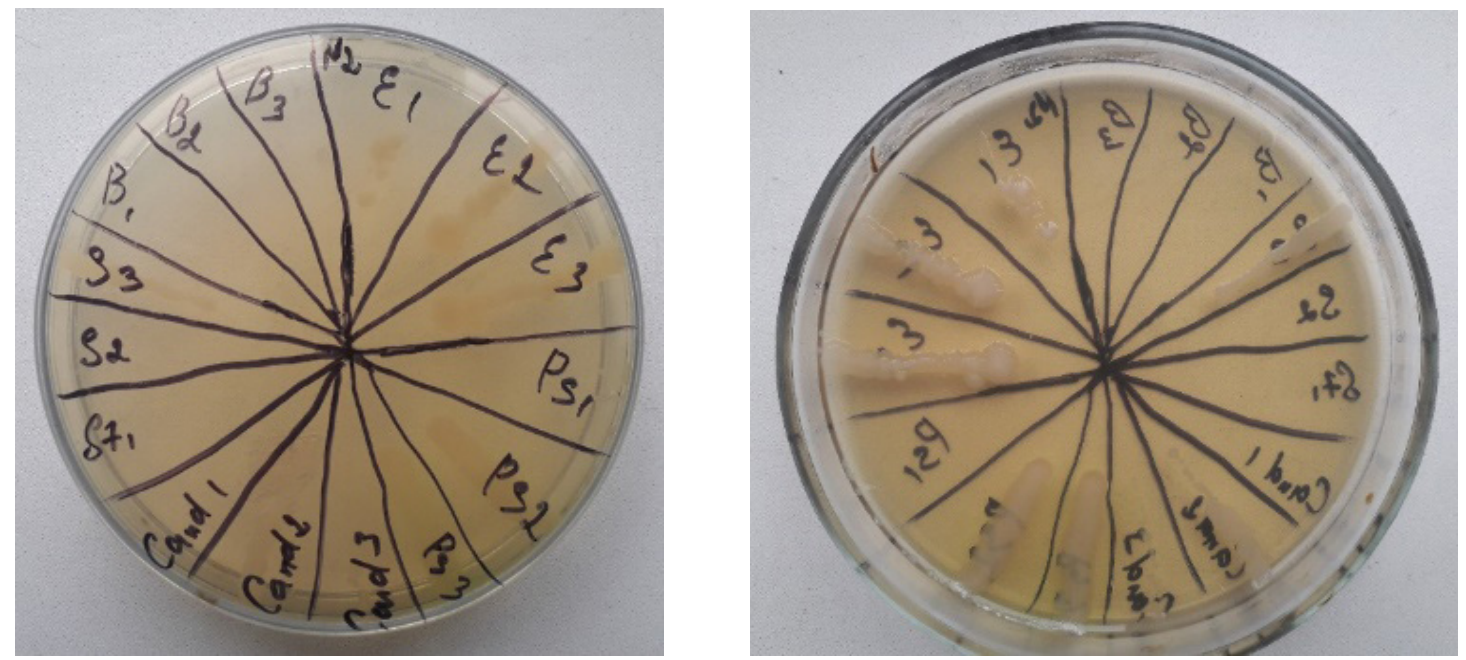

Рис. 2. Результати визначення чутливості тест-штамів до БАР бедринцю ломикаменевого екстракту густого (БЕГ-2).

Таблиця 1. Дослідження антимікробної активності бедринцю ломикаменевого екстракту густого методом серійних розведень

\begin{tabular}{|c|c|c|c|}
\hline \multirow{2}{*}{$\begin{array}{l}\text { Еталонні штами } \\
\text { мікроорганізмів }\end{array}$} & \multirow{2}{*}{$\begin{array}{l}\text { Нативний } \\
\text { зразок }\end{array}$} & \multicolumn{2}{|c|}{ Розведення } \\
\hline & & $1: 2$ & $1: 4$ \\
\hline \multicolumn{4}{|c|}{ БЕГ-1 } \\
\hline Staphylococcus aureus ATCC 6538 & бактерицидна & бактеріостатична & бактеріостатична \\
\hline Bacillus subtilis ATCC 6633 & бактерицидна & бактерицидна & бактерицидна \\
\hline Escherichia coli ATCC 25922 & не проявило дії & не проявило дії & не проявило дії \\
\hline Pseudomonas aeruginosa ATCC 9027 & бактеріостатична & не проявило дії & не проявило дії \\
\hline Candida albicans ATCC 885-653 & бактерицидна & бактеріостатична & бактеріостатична \\
\hline \multicolumn{4}{|c|}{ БЕГ-2 } \\
\hline Staphylococcus aureus ATCC 6538 & бактерицидна & бактерицидна & бактеріостатична \\
\hline Bacillus subtilis ATCC 6633 & бактерицидна & бактерицидна & бактерицидна \\
\hline Escherichia coli ATCC 25922 & бактерицидна & не проявило дії & не проявило дії \\
\hline Pseudomonas aeruginosa ATCC 9027 & бактерицидна & не проявило дії & не проявило дії \\
\hline Candida albicans ATCC 885-653 & бактерицидна & бактеріостатична & бактеріостатична \\
\hline
\end{tabular}

розведені 1:2 та 1:4 проявляв бактерицидну та бактеріостатичну дію відносно S. aureus, B. subtilis, C. albicans. Антимікробна дія по відношенню до E. coli та $P$. aeruginosa не виявлена.

Антимікробну активність нативного бедринцю ломикаменевого екстракту густого також вивчали у дослідах in vitro методом дифузії в агар - метод «колодязів» $[11,12]$.

Облік результатів проводили шляхом вимірювання зони пригнічення росту мікроорганізмів, включно діаметр лунок. Вимірювання проводили з точністю до 1 мм, при цьому орієнтувались на повну відсутність видимого росту. Діаметр зони затримки росту мікроорганізмів характеризував антимікробну активність експериментальних зразків:

- відсутність зон затримки росту мікроорганізмів навколо лунки та зону діаметром до 10 мм оцінювали як нечутливість мікроорганізмів до зразка;
- зони діаметром 11-15 мм оцінювали як помірну чутливість культури до концентрації діючої протимікробної речовини, що досліджувалась;

- зони затримки росту діаметром 1-25 мм - чутливий штам мікроорганізму до досліджуваного зразка;

- зони затримки росту, діаметр яких перевищував 25 мм, свідчить про високу чутливість мікроорганізмів до досліджуваного зразка [13].

Результати досліджень антимікробної активності бедринцю ломикаменевого підземних органів екстракту густого наведено на рисунках 3,4 та у таблиці 2.

Результати досліджень свідчать, що бактеріальні штами S. aureus, C. albicans, B. subtilis, P. aeruginosa, E. coli проявили чутливість до нативного бедринцю ломикаменевого підземних органів екстракту густого.

Слід зазначити, що грампозитивні бактеріальні штами S. aureus, C. albicans, B. subtilis $€$ найбільш

ISSN 2312-0967. Фармацевтичний часопис. 2019. № 1 
Фармакологічні дослідження біологічно активних речовин Pharmacological researches of biologically active substances
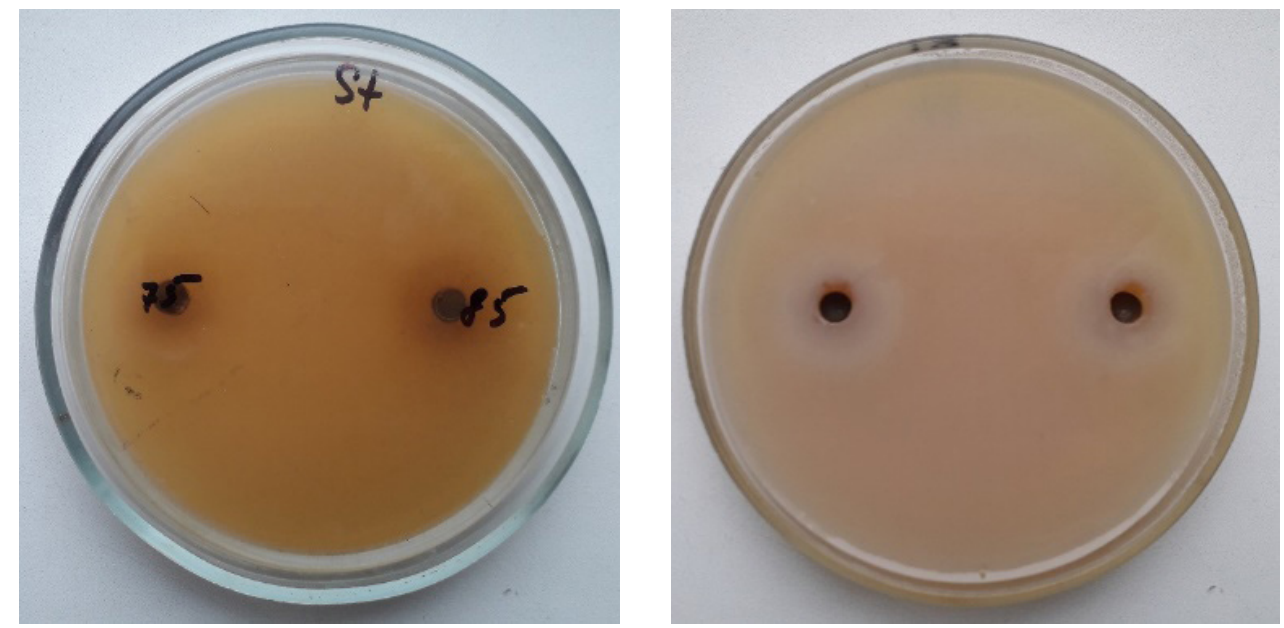

Рис. 3. Результати визначення чутливості біологічно активних речовин бедринцю ломикаменевого екстракту густого до Staphylococcus aureus.
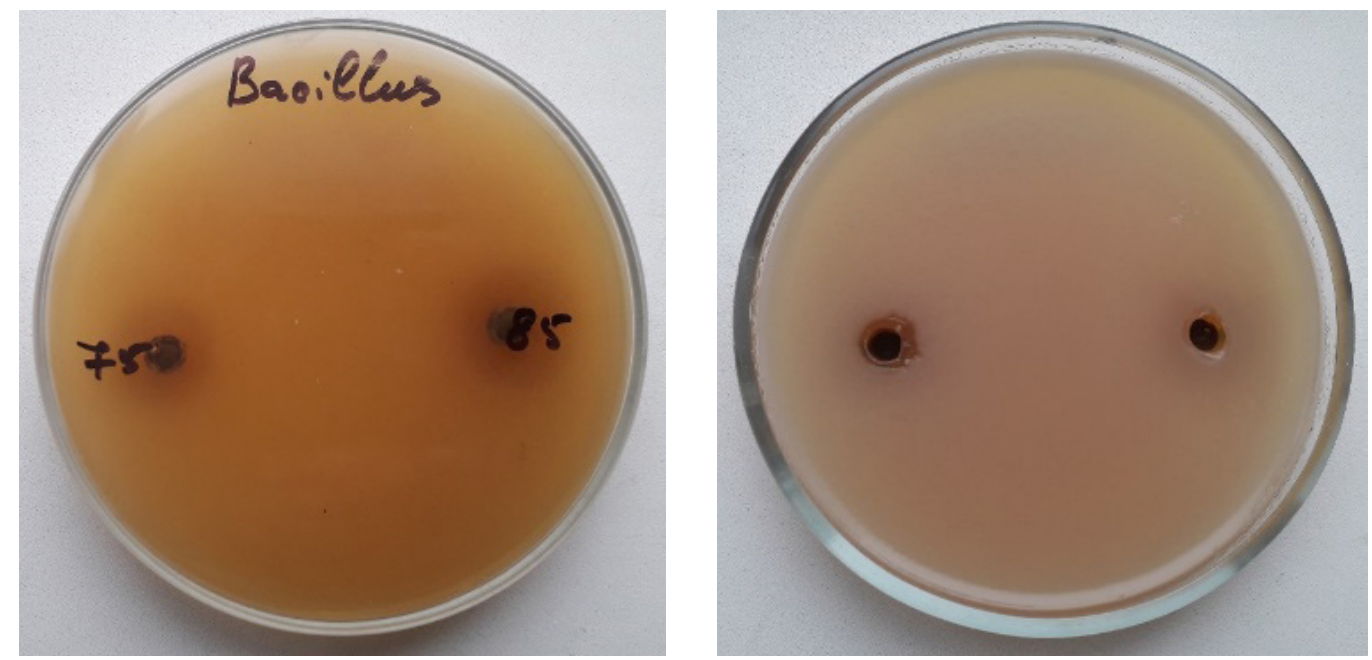

Рис. 4. Результати визначення чутливості біологічно активних речовин бедринцю ломикаменевого екстракту густого до Bacillus subtilis.

Таблиця 2. Дослідження антимікробної активності бедринцю ломикаменевого підземних органів екстракту густого методом дисузії в агар (метод - «колодязів»)

\begin{tabular}{|c|c|c|c|c|c|}
\hline \multirow{3}{*}{ Зразок } & \multicolumn{5}{|c|}{ Культури мікрооганізмів } \\
\hline & $\begin{array}{c}\text { Staphylococcus } \\
\text { aureus } \\
\text { (ATCC 6538) }\end{array}$ & $\begin{array}{l}\text { Bacillus subtilis } \\
\text { (ATCC 6633) }\end{array}$ & $\begin{array}{l}\text { Escherichia coli } \\
\text { (ATCC 25922) }\end{array}$ & $\begin{array}{c}\text { Pseudomonas } \\
\text { aeruginosa } \\
\text { (ATCC 9027) }\end{array}$ & $\begin{array}{c}\text { Candida albicans } \\
\text { (ATCC } \\
885-653)\end{array}$ \\
\hline & \multicolumn{5}{|c|}{ Діаметри зон затримки росту, мм } \\
\hline БЕГ-1 & $17,1 \pm 0,7$ & $14,0 \pm 0,8$ & $12,4 \pm 0,9$ & $12,0 \pm 0,9$ & $11,1 \pm 0,9$ \\
\hline БЕГ-2 & $25,0 \pm 0,5$ & $21,1 \pm 0,6$ & $18,0 \pm 0,7$ & $15,2 \pm 0,8$ & $20,3 \pm 0,7$ \\
\hline
\end{tabular}

чутливими до БЕГ-2 (діаметри зони пригнічення рос-

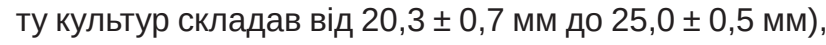
а БЕГ-1 проявляв порівняно меншу чутливість (діаметри зони пригнічення росту культур складали від 11,1 \pm 0,9 мм до 17,1 \pm 0,7 мм).

Грамнегативні культури P. aeruginosa та E. coli проявили помірну чутливість до БЕГ-1 (діаметри зони пригнічення росту культур складали від 12,0 \pm 0,9 мм до 12,4 \pm 0,9 мм), але значно більшу чутливість до БЕГ-2 (діаметри зони пригнічення росту культур складають від 15,2 \pm 0,8 мм до 18,0 \pm 0,7 мм).

Висновки. 1. Експериментально встановлено, що обидва досліджувані зразки бедринцю ломикаменевого підземних органів екстракту густого проявляють антибактеріальну активність.

ISSN 2312-0967. Pharmaceutical review. 2019. № 1 
Фармакологічні дослідження біологічно активних речовин Pharmacological researches of biologically active substances

2. Бедринцю ломикаменевого підземних органів екстрактр густий проявляв більш виражену антимікробну активність щодо грампозитивної мікрофрлори, тому є перспективним для створення лікарського за-

собу з антимікробними властивостями.

Конфлікт інтересів: відсутній.

Conflicts of interest: author has no conflict of interest to declare.

\title{
ОПРЕДЕЛЕНИЕ АНТИМИКРОБНОЙ АКТИВНОСТИ БЕДРЕНЦА КАМНЕЛОМКОВОГО ЭКСТРАКТА ГУСТОГО
}

\author{
Е. А. Паращук, Н. И. Ткачук, С. М. Марчишин, Г. Р. Козыр \\ ГВУЗ «Тернопольский государственный медицинский университет имени И. Я. Горбачевского МОЗ \\ Украины» \\ svitlanafarm@ukr.net
}

Цель работы. Определение антимикробной активности бедренца камнеломкового подземных органов экстракта густого.

Материалы и методы. Объектом для исследования был избран бедренца камнеломкового подземных органов экстракт густой (БЭГ-1, полученный экстрагированием 75 \% этанолом и БЭГ-2, экстрагент 85 \% этанол). В качестве тест-культур использовали 5 музейных штаммов: грамположительные микроорганизмы Staphylococcus aureus ATCC 6538, споровую культуру Bacillus subtilis ATCC 6633, грамотрицательные культуру Escherichia coli ATCC 25922 и Pseudomonas aeruginosa ATCC 9027. Антифрунгальное действие выясняли относительно Candida albicans ATCC 885-653.

Бактериостатические свойства исследуемых объектов устанавливали по результатам роста эталонных штаммов микроорганизмов в нативном водном растворе бедренца и в разведении 1:2 и 1:4 в мясо-пептонном бульоне; бактерицидные - за отсутствием роста содержания пробирок с разведением экстракта на плотных питательных средах (мясопептонный агар - МПА) для грамположительных микроорганизмов S. aureus, B. subtilis, для грамотрицательной культуры E. coli, P. aeruginosa. Агар Сабуро использовали для дрожжеподобных грибов рода Candida (C. albicans).

Результаты и обсуждение. Бедренца камнеломкового подземных органов экстракт густой имеет широкий спектр антибактериальной активности. Нативный экстракт БЭГ-1 по отношению к тест-штаммам S. aureus, B. subtilis, C. albicans проявлял бактерицидное действие. Бактериостатическое действие он проявлял к $P$. aeruginosa, a по отношению к E. coli антимикробного эффректа не обнаружено. Экстракты в разведены 1:2 и 1:4 проявили бактерицидное действие в отношении B. subtilis, бактериостатическое-кS. aureus, C. albicans и не обнаруженопротивомикробногодействиякE. colin P. aeruginosa. Нативный образец БЭГ-2 по отношению ко всем исследуемых 5 тест-штаммам проявил бактерицидную активность; в разведены 1:2 и 1:4 проявлял бактерицидное и бактериостатическое действие в отношении S. aureus, B. subtilis, C. albicans. Антимикробное действие по отношению к E. coli и P. aeruginosa не выявлено.

Антимикробную активность нативного бедренца камнеломкового экстракта густого также изучали в опытах in vitro методом дифффузии в агар - метод «колодцев». Бактериальные штаммы S. aureus, C. albicans, B. subtilis, $P$. aeruginosa, E. coli проявили чувствительность к нативному бедренца камнеломкового экстракту густому. Грамположительные бактериальные штаммы S. aureus, C. albicans, B. subtilis являются наиболее чувствительными к БЭГ-2, а БЭГ-1 проявлял сравнительно меньшую чувствительность. Грамотрицательные культуры $P$. aeruginosa и E. coli также проявили умеренную чувствительность к БЭГ-1, но значительно большую чувствительность к БЭГ-2.

Выводы. Экспериментально установлено, что оба исследуемые образцы бедренца камнеломкового подземных органов экстракта густого проявляют антибактериальную активность.

Бедренца камнеломкового подземных органов экстракт густой проявлял более выраженную антимикробную активность по отношению к грамположительной микрофрлоре (S. aureus, B. subtilis), поэтому является перспективным для создания лекарственного средства с антимикробными свойствами.

Ключевые слова: бедренец камнеломковый; экстракт густой; антимикробное действие.

\section{DETERMINATION OF ANTIMICROBIAL ACTIVITY OF SAXIFRAGE PIMPINELLA DRY EXTRACT}

\author{
E. A. Parashchuk, N. I. Tkachuk, S. M. Marchyshyn, H. R. Kozyr \\ I. Horbachevsky Ternopil State Medical University \\ svitlanafarm@ukr.net
}

The aim of the work. Determination of antimicrobial activity of subterraneous organs of the saxifrage pimpinella dry extract.

ISSN 2312-0967. Фармацевтичний часопис. 2019. № 1 
Materials and Methods. The object for research was chosen subterraneous organs of the saxifrage pimpinella dry extract (pimpenella thick extract-1, obtained by extraction with $75 \%$ ethanol and pimpenella thick extract- 2 , extractant $85 \%$ ethanol). Five archival strains were used as test cultures: gram-positive microorganisms Staphylococcus aureus ATCC 6538, spore culture Bacillus subtilis ATCC 6633, gram-negative culture of Escherichia coli ATCC 25922 and Pseudomonas aeruginosa ATCC 9027. Antifungal effect was found on Candida albicans ATCC 885-653.

The bacteriostatic properties of the subjects under investigation were determined by the growth of reference strains of microorganisms in the native aqueous solution of the saxifrage pimpinella and in dilution 1:2 and 1:4 in the meat-peptone broth; bactericidal - in the absence of growth of the content of samples with dilution of the extract on dense live nutrients (meat-peptone agar - MPA) for gram-positive microorganisms S. aureus, B. subtilis, for the gram-negative culture of $E$. coli, P. aeruginosa. Agar Saburo was used for yeast-like fungi of the Candida (C. albicans) genus.

Results and Discussion. The subterraneous organs of the saxifrage pimpinella dry extract has a wide range of antibacterial activity. The native extract of pimpenella thick extract- 1 in relation to the test strains of $S$. aureus, B. subtilis, $C$. albicans showed a bactericidal effect. It manifested a bacteriostatic effect to $P$. aeruginosa, but in relation to $E$. coli, the antimicrobial effect was not detected. Extract in dilution 1:2 and 1:4 showed bactericidal action against $B$. subtilis, bacteriostatic - to S. aureus, $C$. albicans and no antimicrobial activity against $E$. coli and $P$. aeruginosa.

The native sample of pimpenella thick extract- 2 in relation to all 5 tested strains tested showed bactericidal activity; in dilution of 1:2 and 1:4 showed bactericidal and bacteriostatic effects on S. aureus, B. subtilis, C. albicans. Antimicrobial activity against $E$. coli and $P$. aeruginosa was not detected.

The antimicrobial activity of the native saxifrage pimpinella dry extract was also studied by in vitro method of diffusion into agar - the method of "wells". Strains S. aureus, C. albicans, B. subtilis, P. aeruginosa, E. coli showed sensitivity to the native subterraneous organs of the saxifrage pimpinella dry extract. Gram-positive bacterial strains of $S$. aureus, as well as C. albicans, $B$. subtilis fungi, are most susceptible to pimpenella thick extract-2, and pimpenella thick extract-1 manifested relatively less sensitivity. Gram-negative cultures $P$. aeruginosa and $E$. coli also showed moderate sensitivity to pimpenella thick extract-1, but significantly greater sensitivity to pimpenella thick extract-2.

Conclusions. 1. It was experimentally established that both investigated samples of the subterraneous organs of the saxifrage pimpinella dry extract manifest antibacterial activity.

2. The subterraneous organs of the saxifrage pimpinella dry extract showed a more pronounced antimicrobial activity in relation to the gram-positive microflora, therefore it is promising for the creation of a medicinal product with antimicrobial properties.

Key words: saxifrage pimpinella; thick extract; antimicrobial activity.

\section{Список літератури}

1. Рослини 3 протимікробними властивостями / H Є. Стадницька, О. 3. Комаровська-Порохнявець, Х. Я. Кіщак [та ін.] // Вісник Національного університету «Львівська політехніка». - 2011. - № 700 : Хімія, технологія речовин та їх застосування. - С. 111-116.

2. Котюк Л. А. Антимікробна активність ефріроолійних рослин родини Laminaceae Lindl. щодо Escherichia coli / Л. А. Котюк // Біологічний вісник МДПУ. - 2016. - № 1. - C. 216-236.

3. Dehghanzadeh N. Essential oil composition and antibacterial activity of Hyssopus officinalis L. grown in Iran / N. Dehghanzadeh, S. Ketabci, A Alizaden // Asian. J. Biol. Sci. - 2012. - Vol. 3(4). - P. 767-771.

4. Марчишин С. М. Лікарські рослини Тернопільщини / С. М. Марчишин, Н. О. Сушко. - Тернопіль : Навчальна книга - Богдан, 2007. - С. 48-51.

5. Бедренец камнеломковый - перспективный источник для создания новых ффитопрепаратов разнонаправленного действия / Д. В. Семенив, Ю. В. Столетов, Т. А. Куценко [и др.] // Innovative approaches to the development of science: Mater. of international scientific and practical conference June 1, 2018 in Dublin, Ireland / ed. for the production M. A. Holdenblat // NGO "European scientific platform" - 2018. - Part 2. - P.111-115.

6. 100 самых популярных лечебных растений / сост. : В. Рыжская. - Донецк : Мультипресс, 2010. - 287 с.
7. Марчишин С. М. Дослідження карбонових кислот у надземних і підземних органах бедринцю ломикаменевого (Pimpinella saxifrage L.) / С. М. Марчишин. Е. А. Панасюк // Фармація XXI століття : тенденції та перспективи : матеріали VIII Нац. з'їзду фрармацевтів України (Харків, 13-16 вересня, 2016 р.): у 2 т. Т. 1 / М-во охорони здоров'я України, Нац. фармац. ун-т; кол. : В. П. Черних (голова) та ін.; С. Ю. Данильченко та ін. - Харків : НФаУ, 2016. - C. 112.

8. Phenolic compounds from Pimpinella saxifraga L. I S. Marchyshyn, E. Parashchuk, I. Dakhym, L. Husak. - The Pharma Innovation Journal. - 2018. - № 7(6). P. 600-602.

9. Паращук Е. А. Дослідження летких компонентів бедринцю ломикаменевого (Pimpinella saxifraga L.) / Е. А. Паращук, С. М. Марчишин, Л. В. Слободянюк // Медична та клінічна хімія. - 2018. - Т. 20, № 4. - С. 107113.

10. Практична мікробіологія / за ред. Широбоков В. П., Климнюк С. І. - Вінниця: Нова книга, 2018. - С. 78-81. 11. Вивчення специфічної активності протимікробних лікарських засобів : метод. реком / Ю. Л. Волянський, І. С. Гриценко, В. П. Широбоков [та ін.]. - Київ, 2004. $38 \mathrm{c}$.

12. Державна Фармакопея України / Державне підприємство «Науковоекспертний фармакопейний центр». -

ISSN 2312-0967. Pharmaceutical review. 2019. № 1 
Фармакологічні дослідження біологічно активних речовин Pharmacological researches of biologically active substances

1-е вид. - Харків : РІРЕГ, 2011. Доповнення 4. - 536 с. 13. Маслій Ю. С. Мікробіологічне обґрунтування вибору АФІ та їх концентрацій у складі стоматологічного гелю
/ Ю. С. Маслій, О. А. Рубан, О. П. Стрілець // Український біофармацевтичний журнал. - 2017. - № 1 (48). - C. 58-63.

\section{References}

1. Stadnytska NYe, Komarovska-Porokhniavets KhYa, Kishchak KhYa, Mykoliv OB, Lytvyn BYa, Konechna RT, Novikov VP [Plants with antimicrobial properties]. Visnyk nats un-tu "Lvivska Politekhnika". 2011;700: 111-6. Ukrainian.

2. Kotiuk LA. [Antimicrobial activity of erophilic plants of Laminaceae Lindl family as regards Escherichia coli]. Biol visn MDPU. 2016;1: 216-36. Ukrainain.

3. Dehghanzadeh N, Ketabci S, Alizaden A. Essential oil composition and antibacterial activity of Hyssopus officinalis L. grown in Iran. Asian J Biol Sci. 2012;3(4): 767-71.

4. Marchyshyn SM, Sushko NO. Medicinal plants of Ternopil region. [Лікарські рослини Тернопільщини] Ternopil: Navchalna knyha Bohdan; 2007. Ukrainian.

5. Semeniv DV, Stoletov YuV, Kutsenko TA Pimpinella saxifrage a promising source for the creation of new multidirectional herbal remedies. Innovative approaches to the development of science: Mater. of international scientific and practical conference June 1, 2018 in Dublin, Ireland Ed. for the production Holdenblat MA. NGO "European scientific platform"; 2018. Russian.

6. Ryzhskaya V. 100 most popular medicinal plants [100 самых популярных лечебных растений] Donetsk: Multypress. Russian.

7. Marchyshyn SM, Panasiuk EA. Investigation of carboxy- lic acids in the aboveground and underground organs of the pimpinella saxifrage (Pimpinella saxifrage L.) Pharmacy of the 21st Century: Trends and Prospects: Materials of the VIII National Academy of Sciences of Ukraine. the Congress of Pharmacists of Ukraine.2016 Sep 13-6; Kharkiv: NPhaU. Ukrainian.

8. Marchyshyn S, Parashchuk E, Dakhym I, Husak L. Phenolic compounds from Pimpinella saxifraga L. The Pharma Innovation Journal. 2018;7(6): 600-2.

9. Parashchuk EA. [Investigation of volatile component of the pimpinella saxifrage (Pimpinella saxifraga L.)]. Med ta klin khimiia. 2018;20(4): 107-13. Ukrainian.

10. Shyrobokov VP, Klymniuk SI Practical microbiology. [Практична мікробіологія]. Vinnytsia: Nova Knyha; 2018. Ukrainian.

11. Volianskyi YuL, Hrytsenko IS, Shyrobokov VP Study of specific activity of antimicrobial drugs: guidelines. [Вивчення специфічної активності протимікробних лікарських засобів: метод. Реком.] Kyiv; 2004. Ukrainian. 12. State Pharmacopoeia of Ukraine. [Державна Фармакопея України] Kharkiv: RIREH; 2011. Ukrainian.

13. Maslii Yus, Ruban OA, Strilets OP. [Microbiological substantiation of the choice of AFI and their concentrations in the composition of the dental gel]. Ukr biofarm zhurn. 2017;1(48): 58-63. Ukrainian.

Надійшла до редакції / Received: 06.03.2019

Після доопрацювання / Revised: 19.03.2019 Прийнято до друку / Accepted: 20.03.2019

\section{Відомості про авторів:}

Паращук Е.А. - магістр фрармації, асистент кафр. фрармакогнозії з медичною ботанікою, Тернопільський державний медичний університет імені І. Я. Горбачевського, Тернопіль, Україна. E-mail: panasiuk_e@tdmu.edu.ua, ORCID 00000003-0191-7956

Ткачук H.І. - канд. мед. н., доц. кафр. мікробіології, вірусології та імунології, Тернопільський державний медичний університет імені I. Я. Горбачевського, Тернопіль, Україна. E-mail: tkachuk@tdmu.edu.ua, ORCID 0000-0003-3046-3009 Марчишин С.М. - д-р фармац. н., профр., зав. каф. фрармакогнозії з медичною ботанікою, Тернопільський державний медичний університет імені I. Я. Горбачевського, Тернопіль, Україна. E-mail: svitlanafarm@ukr.net, ORCID 0000-00019585-1251

Козир Г.Р. - канд. фрармац. н., доц. каф. управління та економіки фрармації з технологією ліків, Тернопільський державний медичний університет імені I. Я. Горбачевського МО3 України, Тернопіль, Україна. E-mail: kozyr@tdmu. edu.ua, ORCID 0000-0002-4466-5157

\section{Information about the authors:}

Parashchuk E.A. - Master (Pharmacy), Assistant of the Pharmacognosy and Medical Botany Department, I. Horbachevsky Ternopil State Medical University, Ternopil, Ukraine. E-mail: panasiuk_e@tdmu.edu.ua, ORCID 0000-0003-0191-7956 Tkachuk N.I. - PhD (Medicine), Associate Professor of the Microbiology, Virology and Immunology Department, I. Horbachevsky Ternopil State Medical University, Ternopil, Ukraine. E-mail: tkachuk@tdmu.edu.ua, ORCID 0000-0003-3046-3009

Marchyshyn S.M. - DS (Pharmaceutical Sciences), Professor, Head of the Department of Pharmacognosy and Medical Botany, I. Horbachevsky Ternopil State Medical University, Ternopil, Ukraine. E-mail: svitlanafarm@ukr.net, ORCID 00000001-9585-1251

Kozyr G.R. - PhD (Pharmaceutical Sciences), Associate Professor of the Organization and Economic of pharmacy with Drug Technology Department, I. Horbachevsky Ternopil State Medical University, Ternopil, Ukraine. E-mail: kozyr@tdmu. edu.ua, ORCID 0000-0002-4466-5157

ISSN 2312-0967. Фармацевтичний часопис. 2019. № 1 